\title{
Germination of Crotalaria and Lupinus (Fabaceae) seeds submitted to different pre-germination treatments and their effect on enzymatic activity during early germination
}

\author{
B. Garduza-Acosta ${ }^{a}$ (D), L. C. Lagunes-Espinoza* (D), C. C. Bautista-Muñoz ${ }^{a}$ (D), \\ G. García-de-los-Santos ${ }^{b}$ (D), J. M. Zaldivar-Cruz ${ }^{a}$ (D) and A. Hernández-Flores ${ }^{a}$ (D) \\ aLaboratório de Fisiologia Vegetal, Pós-graduação em Produção Agroalimentar nos Trópicos, Área Agrícola, Colegio de \\ Postgraduados - CP, Campus Tabasco, Periférico Carlos A. Molina, s/n, 86500, H. Cárdenas, Tabasco, México \\ 'Pós-graduação em Produção de Sementes, Área de Produção e Tecnologia de Sementes, Colegio de Postgraduados - CP, \\ Campus Montecillo, Km 36.5, Carretera México-Texcoco, 56230, Montecillo, Texcoco, Edo de México, México \\ *e-mail: lagunesc@colpos.mx
}

Received: September 26, 2017 - Accepted: May 16, 2018 - Distributed: February 28, 2020 (With 4 figures)

\begin{abstract}
Most of the wild and native legume seeds has a hard and impermeable testa, which causes physical dormancy and prevents them from germinating even when environmental conditions are favorable. The study evaluated the effect of scarification treatments on germination and enzymatic activity of Crotalaria longirostrata $(C l)$ and Lupinus exaltatus ( $L e$ ) seeds. After scarification treatments, germination percentage (GP) and rate (GR) were assessed during 30 days after seeding (DAS); and water absorption (WA) and specific enzymatic activity (SEA) during early germination $(0,6,18,36,72,120 \mathrm{~h})$ in a growing chamber at $25^{\circ} \mathrm{C}$ and photoperiod of $12 \mathrm{~h}$. Scarification with $98 \% \mathrm{H}_{2} \mathrm{SO}_{4} 15 \mathrm{~min}$ increased GP and GR in both species. At 30 DAS, GP and GR of $L e$ seeds were $34 \%$ and 0.97 seeds day ${ }^{-1}$, respectively. In $\mathrm{Cl}$ seeds, GP was $64 \%$ and GR 0.90 seeds day ${ }^{-1}$. Scarification with $\mathrm{H}_{2} \mathrm{O}$ at $80^{\circ} \mathrm{C} 1 \mathrm{~min}$ also promoted germination in $\mathrm{Cl}(52 \%)$. At $120 \mathrm{~h}$ after seeding, $\mathrm{Le}$ and $\mathrm{Cl}$ seeds showed already a high GP with acid scarification (31\% and 48\%, respectively). In seeds of both species, scarification treatments affected WA and SEA during early germination. During this period, scarification treatments that increased GP also showed a higher $\alpha$-D-galactosidase activity. The maximum enzyme activity was observed $72 \mathrm{~h}$ after hot water scarification in $\mathrm{Cl}$ (82.6 U/mg total protein), followed by acid scarification (54.5 U/mg total protein). In Le, the activity peak was $36 \mathrm{~h}$ after acid scarification $(9.5 \mathrm{U} / \mathrm{mg}$ total protein). No relationship was observed between $\beta$-glucosidase activity and GP in both species. In conclusion, during early germination of both species, the increase in GP is accompanied by a rise in $\alpha$-D-galactosidase activity between 36 and $72 \mathrm{~h}$ after seeding; and in $\mathrm{Cl}$ seeds, an alternative scarification treatment to increase GP may be the use of hot water.
\end{abstract}

Keywords: scarification, native legumes, enzymes.

\section{Germinação de sementes de Crotalaria e Lupinus (Fabaceae) submetidas a diferentes tratamentos pré-germinativos e o efeito da atividade enzimática na fase inicial da germinação}

\section{Resumo}

A maioria das sementes de leguminosas nativas e selvagens têm um tegumento rígido e impermeável, o que causa dormência física e impede a germinação, mesmo se as condições ambientais forem favoráveis. O estudo avaliou o efeito de tratamentos de escarificação sobre a germinação e a atividade enzimática de sementes de Crotalaria longirostrata $(\mathrm{Cl})$ e Lupinus exaltatus ( $(\mathrm{Le})$. Após os tratamentos de escarificação, a percentagem (PG) e a velocidade de germinação (VG) foram avaliadas durante 30 dias após a semeadura (DAS); absorção de água (AA) e atividade enzimática específica (AEE) na fase inicial da germinação $(0,6,18,36,72$ e $120 \mathrm{~h})$ em uma câmara de crescimento a $25^{\circ} \mathrm{C}$ e fotoperíodo de 12 h. A escarificação com $98 \%$ de $\mathrm{H}_{2} \mathrm{SO}_{4}$, durante 15 min aumentou PG e VG nas duas espécies. Aos 30 DDS, PG e VG de sementes de $L e$ foram de $34 \%$ e 0,97 sementes dia ${ }^{-1}$, respectivamente. Em sementes de $\mathrm{Cl}$, PG foi de $64 \%$ e VG 0,90 sementes dias ${ }^{-1}$. A escarificação com $\mathrm{H}_{2} \mathrm{O}$ a $80^{\circ} \mathrm{C} 1$ min também promoveu a germinação em $\mathrm{Cl}(52 \%)$. A 120 h após a semeadura, as sementes de $C l$ e $L e$ já tinha atingido uma alta PG com escarificação ácida ( $31 \%$ e $48 \%$, respectivamente). Nas sementes das duas espécies, os tratamentos de escarificação afetaram a AEE e a AA nafase inicial da germinação. Durante este período, os tratamentos de escarificação que aumentaram PG, também mostraram a atividade mais elevada de $\alpha$-D-galactosidase. A atividade enzimática máxima foi observada $72 \mathrm{~h}$ após o tratamento com água quente em $C l(82,6 \mathrm{U} / \mathrm{mg}$ de proteína total), seguido por escarificação ácida (54,5 U/mg de proteína total). 
Em $L e$, o pico de atividade foi de $36 \mathrm{~h}$ após a aplicação do tratamento ácido (9,5 U/mg de proteína total). Em contraste, não foi observado nenhuma relação entre a actividade $\beta$-glicosidase e PG. Em conclusão, durante a germinação precoce das duas espécies, o aumento da GP é acompanhado por um aumento da atividade da $\alpha$-D-galactosidase entre 36 e $72 \mathrm{~h}$ após a semeadura; e em sementes de $\mathrm{Cl}$, um tratamento de escarificação alternativo para aumentar GP pode ser o uso de água quente.

Palavras-chave: escarificação, leguminosas nativas, enzimas.

\section{Introduction}

Legumes are essential components of ecosystems and crop systems because of the biological capacity to fix atmospheric nitrogen. They have a vital role in food security and in resilience from effects of climate change (Liew et al., 2014). In Mexico, they constitute the second largest family of Phanerogamae (Sousa and Delgado, 1998), and a high percentage are semi-domesticated or are still wild (Fraile et al., 2007).

A limitation for the agronomic use or ecological restoration of most of the legume seeds is that they do not germinate even when environmental conditions are favorable because of their hard, impermeable testa, which causes physical dormancy (Jeller et al., 2003; Smýkal et al., 2014). In breaking dormancy in this type of seeds, scarification treatments applied affect seed imbibition (Bewley et al., 2013). Application of acid or heat treatments can release physical dormancy in legumes seeds; and effectivity of these scarification treatments to promote germination range from 12 to $100 \%$ in Lupinus and Crotalaria species (Elliott et al., 2011; Alderete-Chávez et al., 2010a, b; Ayala-Herrada et al., 2010; Tiryaki and Topu, 2014).

Scarification treatments that break physical dormancy could have an effect on the composition, distribution of nutrients and enzymatic activity during dormancy release. In dormant seeds, the water content and metabolic rate is low, but a few enzymes are active, as $\alpha$-galactosidase (Guimarães et al., 2001; Fialho et al., 2008). The activity of $\alpha$-galactosidase and other hydrolases increases during the polysaccharides hydrolysis in the early stages of seed germination (Minic, 2008; Buckeridge, 2010; Bewley et al., 2013). The application of scarification treatments, weaken the cell walls, allowing to water enter; the seed hydrated increases metabolic activity, particularly enzyme in the endosperm or cotyledons for synthesis of new materials and embryo growth (Bewley et al., 2013; Kamithi et al., 2016). In Euphorbia heterophylla L. seeds, high levels of $\alpha$-D-galactosidase are detected during the period of imbibition, related to reduction of endosperm resistance to cotyledon expansion (Suda et al., 2003). In L. angustifolius this enzyme catalyzes hydrolysis of galactans in the cell walls of cotyledons during early stages of germination (Buckeridge et al., 2005), and in Arabidopsis seeds B-glucosidase, seems to be involved in the embryo cell wall loosening needed for cell elongation and radicle extension (Gallardo et al., 2002).

Species from the Lupinus and Crotalaria genus are abundant in ecosystem of Mexico (Acosta-Percástegui and Rodríguez-Trejo, 2005; Ayala-Herrada et al., 2010;
Lagunes-Espinoza et al., 2012; Soto-Correa et al., 2015). Seed dormancy of these legumes can be broken by physical (Pablo-Pérez et al., 2013) or chemical treatments (Ayala-Herrada et al., 2010; Acosta-Percástegui and Rodríguez-Trejo, 2005). Water absorption by seeds after scarification treatments enhances mobilization of nutrients and enzyme activity, required for rapid seed germination, so that scarification treatments could have a beneficial effect on enzyme activities involved in early germination (Kamithi et al., 2016). In Lupinus and Crotalaria, few studies have focused on the effect of scarification treatments in the increase of enzymes activity during early germination that can be relationship with germination. In the present study, the effect of scarification treatments on percentage and rate of germination during time and specific enzyme activity of $\beta$-glucosidase and $\alpha$-D-galactosidase in early germination were studied in C. longirostrata and L. exaltatus seeds.

\section{Material and Methods}

Dry fruits of L. exaltatus L. were collected in August 2014 (summer season), and those of Crotalaria longirostrata Hook. \& Arn. fruits in September 2013 (autumn season), from plants grown in agroecosystems of the states of Puebla and Tabasco, Mexico, respectively. The seeds were separated from the dry fruits and conserved at $4{ }^{\circ} \mathrm{C}$ for later analysis.

Before application of scarification treatments, seeds were disinfected 2 min with a $3 \%$ solution of sodium hypochlorite, and washed three times with sterile distilled water. After seed disinfection, seeds of both species were tested for viability. 20 seeds in triplicate per species were disinfected and mechanically scarified to separate the testa from the cotyledons. The cotyledons were submerged in $5 \mathrm{~mL}$ of a $1 \%$ tetrazolium chloride solution and left in darkness for $24 \mathrm{~h}$. The embryos dyed red (viable seeds) were counted. Seed viability was $93 \pm 5.7 \%$ and $90 \pm 5.0 \%$ for C. longirostrata and L. exaltatus, respectively.

After this step, other seeds were used for the scarification treatments. The scarification treatments applied to the seeds of $L$. exaltatus were: I) Immersion in $\mathrm{H}_{2} \mathrm{SO}_{4} 98 \%$ for $15 \mathrm{~min}$ followed by three washes with sterile distilled water; II) Immersion in wet sand for $8 \mathrm{~h}$ at $35^{\circ} \mathrm{C}$, followed by $16 \mathrm{~h}$ at room temperature $\left(23-25^{\circ} \mathrm{C}\right)$; III) Drying seeds at $80{ }^{\circ} \mathrm{C}$ for $7 \mathrm{~min}$, then allowed to cool to room temperature; IV) Drying seeds in dry sand at $150^{\circ} \mathrm{C}$ for $1 \mathrm{~min}$; V) Without scarification (control). In C. longirostrata seeds the treatments applied were: I) Immersion in $\mathrm{H}_{2} \mathrm{SO}_{4}$ $98 \%$ for 15 min followed by three washes with sterile 
distilled water; II) Soaking in distilled water at $80^{\circ} \mathrm{C}$ for $1 \mathrm{~min}$; III) Without scarification (control).

After treatments, groups of 50 seeds in triplicate were sown in Petri dishes disinfected between sterile paper and placed in a bioclimatic chamber (Thermo Scientific) at $25^{\circ} \mathrm{C}$ and $12 \mathrm{~h}$ light photoperiod (Acosta-Percástegui and Rodriguez-Trejo, 2005; Gutierrez-Nava et al., 2010). All lots of seeds were watered with sterile distilled water during the evaluation period. In a separate group of 50 seeds in triplicate, an imbibition test was performed after scarification treatments during $0,6,18,36,72,120$ and $148 \mathrm{~h}$.

Germination percentage (GP) was determined with the formula of Maguire (1962): $G P(\%)=\frac{N G S}{T N S S} \times 100$, where $N G S=$ number of germinated seeds and TNSS = total number of sown seeds. For the germination test, germinated seeds were counted daily during 30 days or $0,6,18,36,72$, and $120 \mathrm{~h}$ after seeding; a seed was considered germinated when the radicle was $\geq 2 \mathrm{~mm}$ long. Germination rate (GR) is defined as the measure of the number of seeds germinated relative to the time of germination, determined with the formula $\mathrm{GR}=\sum(\mathrm{NGSi}) / \mathrm{t}$, where $\mathrm{NGSi}=$ number of germinated seeds on day $\mathrm{i} ; \mathrm{t}=$ germination time from sowing to germination of the last seed.

To detect the peak of maximum enzyme activity during the first hours of seed imbibition, evaluation of enzymatic activity was at $0,6,18,36,72$, and $120 \mathrm{~h}$ after seeding. To $\beta$-glucosidase enzyme activity, samples were powdered homogeneously in liquid $\mathrm{N}_{2}$; de-fatted to obtain acetone-dry powders (ADP) by addition of $95 \%$ hexane $(1: 10 \mathrm{w} / \mathrm{v})$, with constant shaking $(150 \mathrm{rpm})$ for two hours at $4{ }^{\circ} \mathrm{C}$ and centrifuged (10 $000 \mathrm{rpm}$ ) for five min at $4{ }^{\circ} \mathrm{C}$. The supernatant was decanted and the precipitate was left to stand until the solvent evaporated completely. Immediately, three extractions were done successively with $80 \%$ acetone $(1: 3 \mathrm{w} / \mathrm{v})$; between each extraction, the sample was centrifuged $(5,000 \mathrm{rpm})$ for $5 \mathrm{~min}$ at $4{ }^{\circ} \mathrm{C}$. The supernatant was discarded. Finally, one extraction was done with $100 \%$ acetone $(1: 3 \mathrm{w} / \mathrm{v})$ at $10,000 \mathrm{rpm}$ for $5 \mathrm{~min}$ at $4{ }^{\circ} \mathrm{C}$, discarding the supernatant; the residue was left at room temperature until the solvent evaporated completely. The resulting paste (ADP) was powdered and conserved at $-67^{\circ} \mathrm{C}$. Thirty $\mathrm{mg}$ of polyvinylpolypyrrolidone (PVPP) and $900 \mu \mathrm{L}$ of $1 \%$ Triton X100 solution (dissolved in $100 \mathrm{mM} \mathrm{pH} 7.0$ of Tris ultrapure buffer) were added to $15 \mathrm{mg}$ ADP and incubated at $37^{\circ} \mathrm{C}$ in a water bath for $30 \mathrm{~min}$ with constant shaking at $150 \mathrm{rpm}$. The solution was then centrifuged $(10,000 \mathrm{rpm})$ for $10 \mathrm{~min}$ at $4{ }^{\circ} \mathrm{C}$. The supernatant was used to determine $\beta$-glucosidase enzyme activity. $\beta$-glucosidase activity was determined following Ross et al. (1993) and Gerardi et al. (2001): $200 \mu \mathrm{L}$ of the enzyme extract was mixed with $200 \mu \mathrm{L}$ of $125 \mathrm{mM} \mathrm{pH} 4.0$ sodium acetate buffer containing $200 \mathrm{mM}$ 2 - $\beta$-mercaptoethanol, $50 \mathrm{~mL}$ of $40 \mathrm{mM}$ p-nitrophenyl $\beta$-D-glucopyranoside and $350 \mu \mathrm{L}$ sterile deionized water. All was mixed in a vortex and placed in incubation at $30^{\circ} \mathrm{C}$ for $60 \mathrm{~min}$. The reaction was stopped by the addition of $200 \mu \mathrm{L} 1 \mathrm{M} \mathrm{Na}_{2} \mathrm{CO}_{3}$. In the blank samples, enzyme reaction was ended before incubation. Absorbance was determined at $405 \mathrm{~nm}$ in a Thermo Scientific model Multiskan Go spectrophotometer. The type curve was constructed using p-nitrophenol as standard at a concentration of 0 to $100 \mu \mathrm{M}$. One unit of $\beta$-glucosidase was defined as the quantity of enzyme capable of releasing one $\mu \mathrm{M}$ p-nitrophenol per minute.

To $\alpha$-D-galactosidase enzyme activity, samples were powdered with liquid $\mathrm{N}_{2}$, and homogenized with $20 \mathrm{~mL}$ $15 \mathrm{mM}$ trihydrated sodium acetate buffer $\mathrm{pH} 5.5$ solution. The homogenized solution was centrifuged $(10,000 \mathrm{ppm})$ at $4{ }^{\circ} \mathrm{C}$ for five $\min$ (Fialho et al., 2008). Finally, the supernatant was decanted and stored at $-67^{\circ} \mathrm{C}$. Activity was determined following Fialho et al. (2008), using $100 \mu \mathrm{L}$ enzyme extract, $600 \mu \mathrm{L} 200 \mathrm{mM}$ sodium acetate buffer $\mathrm{pH}$ 5, and $50 \mu \mathrm{L}$ $20 \mathrm{mM}$ p-nitrophenol $\alpha$-D- galactopyranoside substrate. The reaction was run for $15 \mathrm{~min}$ at $40^{\circ} \mathrm{C}$ and stopped with the addition of $250 \mu \mathrm{L} 2 \mathrm{M}$ sodium carbonate $\left(\mathrm{Na}_{2} \mathrm{CO}_{3}\right)$, centrifuged $(10,000 \mathrm{rpm})$ for $5 \mathrm{~min}$ at room temperature. For the blanks, the enzyme reaction was stopped before incubation. The amount of p-nitrophenol released was determined at $410 \mathrm{~nm}$. A standard curve of p-nitrophenol of 0 to $100 \mu \mathrm{M}$ was constructed to interpolate the data. One unit of $\alpha$-D-galactosidase was defined as the amount of enzyme capable of releasing one $\mu \mathrm{M}$ p-nitrophenol per minute.

The concentration of total protein in the enzymatic extracts was determined by the micro Markwell method (Markwell et al., 1978). To $20 \mu \mathrm{L}$ of extract, $280 \mu \mathrm{L}$ sterile deionized water was added. While shaking, $1,000 \mu \mathrm{L}$ of a solution composed of $\mathbf{A}$ [ $2 \%$ solution of anhydrous sodium carbonate $\left(\mathrm{Na}_{2} \mathrm{CO}_{3}\right), 0.4 \%$ sodium hydroxide $(\mathrm{NaOH})$, $0.16 \%$ sodium tartrate and potassium $\left(\mathrm{C}_{4} \mathrm{H}_{4} \mathrm{KNaO}_{6} \cdot 4 \mathrm{H}_{2} \mathrm{O}\right)$, $1 \%$ sodium dodecyl sulfate $\left.\left(\mathrm{CH}_{3}\left(\mathrm{CH}_{2}\right)_{11} \mathrm{OSO}_{3} \mathrm{Na}\right)\right]$ was mixed with solution $\mathbf{B}$ [1:100 w/v of cuprous sulfate $\left.\left(\mathrm{CuSO}_{4} \cdot 5 \mathrm{H}_{2} \mathrm{O}\right)\right]$. The mixture was incubated for $15 \mathrm{~min}$ at room temperature, and then while shaking $100 \mu \mathrm{L}$ Folin $\&$ Ciocalteu's reagent $(1: 1$, reagent:water) were added and incubated for $5 \mathrm{~min}$ at $37^{\circ} \mathrm{C}$. The peptides released during the reaction were determined at $660 \mathrm{~nm}$ using bovine serum albumin ( 0 to $100 \mu \mathrm{g} / \mu \mathrm{L})$.

Previous statistical analysis, data on germination percentage were transformed to the arcsine square root to have an approximated normal distribution. All data were subjected, by species, to analysis of variance under a completely randomized design in a factorial array with three replications. The first factor were the scarification treatments, and the second factor was time in days (30 days) or hours $(0,6,18,36,72$ and $120 \mathrm{~h})$. The Tukey means test at 5\% of probability was used to determine significant differences between treatments with SAS 9.3 software.

\section{Results}

The scarification pre-treatments affected germination percentage (GP) and rate (GR) of L. exaltatus and C. longirostrata seeds. Acid scarification pre-treatment increase germination percentage and rate in both species 
(Figure 1). At 30 DAS of $C$. longirostrata seeds had germinated and only $34 \%$ in L. exaltatus. In both species, germination rate decreased with germination time, the highest was five DAS after acid pre-treatment ( 4.8 seeds day ${ }^{-1}$ in C. longirostrata and 3.8 in L. exaltatus). In C. longirostrata, the pre-treatment with moist heat also increased significantly GP and GR (52\% and 3.4 seeds day ${ }^{-1}$, respectively), in relation to control five DAS.
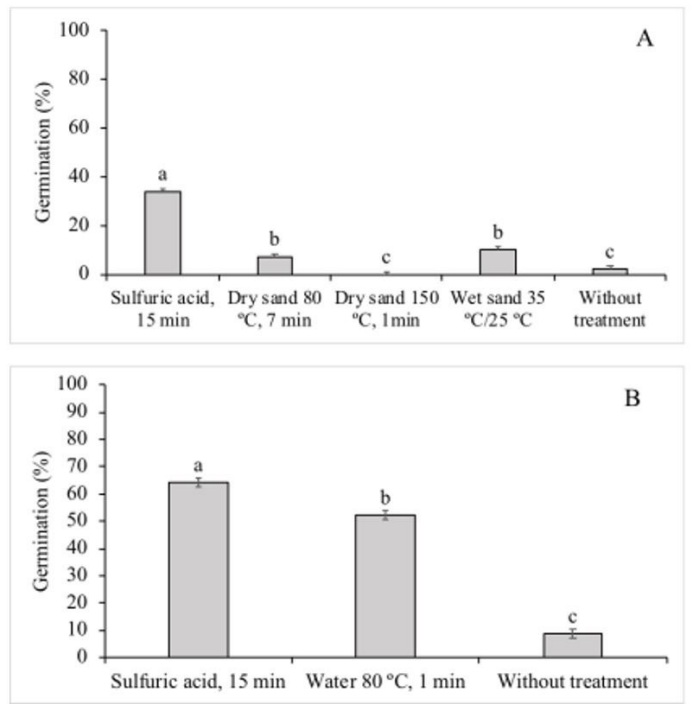

Regarding the GP and GR during early germination, dry heat shock $\left(80^{\circ} \mathrm{C}\right.$ and $\left.150^{\circ} \mathrm{C}\right)$ inhibited the germination process almost entirely in L. exaltatus (Figure 2A and 2B). In contrast, pre-treatment of sulfuric acid $98 \% 15 \mathrm{~min}$ increased GP and GR in L. exaltatus seeds. At the end of $120 \mathrm{~h}$, the seeds had already reached $31 \%$ germination. In contrast to L. exaltatus, the response to germination of $C$. longirostrata seeds to scarification pre-treatment
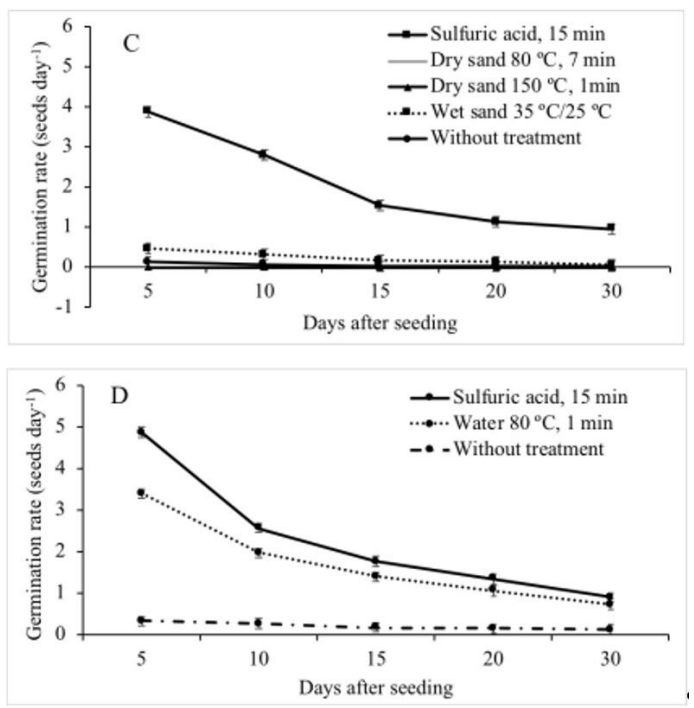

Figure 1. Germination percentage of L. exaltatus (A) and C. longirostrata (B) seeds at 30 days after application of scarification treatments. Germination rate of $L$. exaltatus $(\mathrm{C})$ and $C$. longirostrata $(\mathrm{D})$ seeds during germination time after application of scarification treatments. Different letters by treatments are statistically different (Tukey, $\mathrm{p} \leq 0.05$ ). Error bars represent \pm s.e. $(n=3)$.
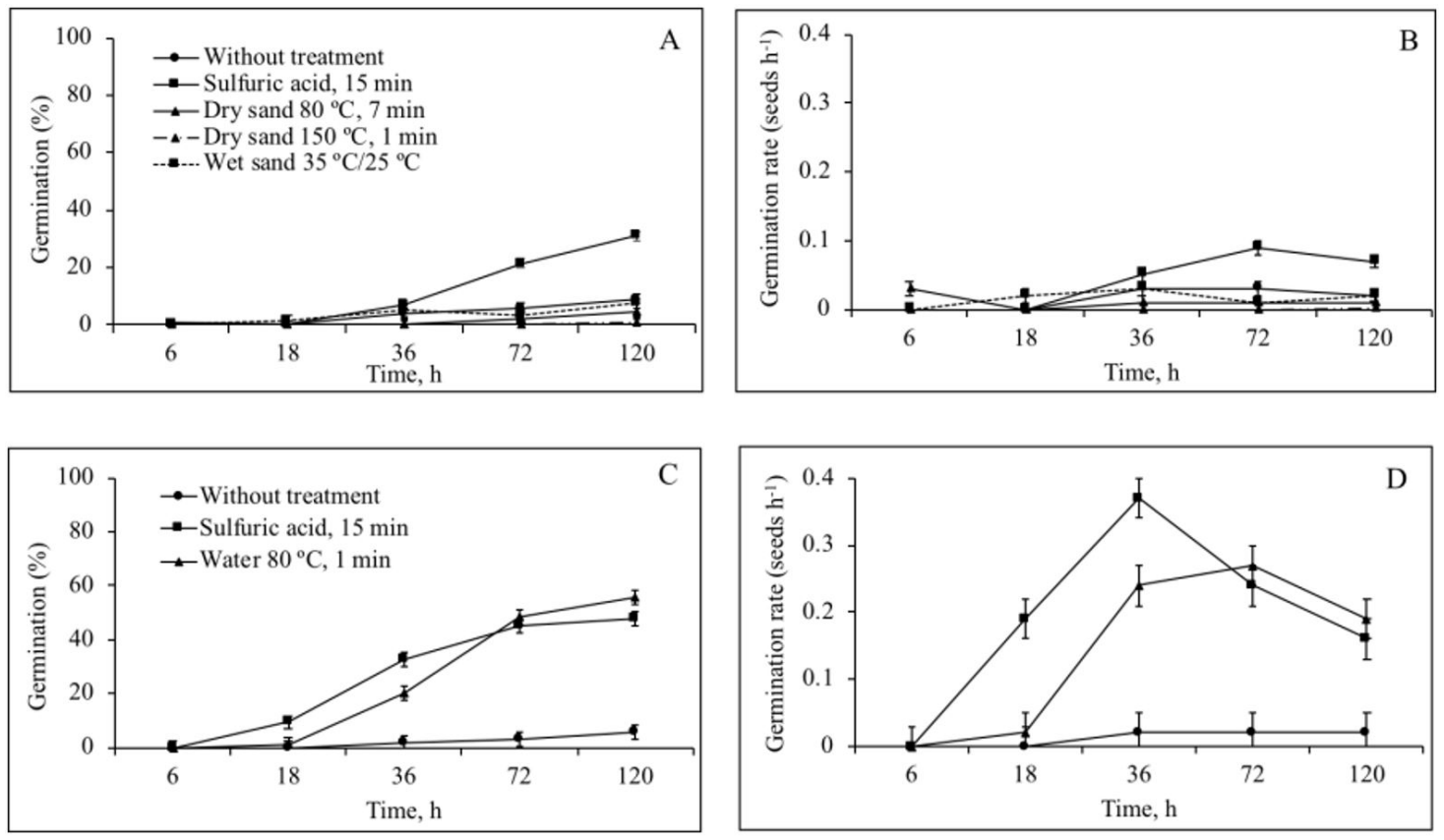

Figure 2. Germination percentage and rate of L. exaltatus (A, B) and C. longirostrata (C, D) seed seed during early germination time $(0,6,18,36,72$ and $120 \mathrm{~h}$ after application of scarification treatments). Different letters by treatments are statistically different (Tukey, $\mathrm{p} \leq 0.05)$. Error bars represent \pm s.e. $(n=3)$. 
was higher (Figure 2C). In this species, no significant differences ( $p \leq 0.0001)$ were observed between treatments with sulfuric acid $98 \%$ and water at $80{ }^{\circ} \mathrm{C}$ on the GR at 120 h. The higher GR was observed with sulfuric acid $\left(0.37\right.$ seeds $\left.h^{-1}\right)$ followed by treatment of immersion in water at $80{ }^{\circ} \mathrm{C}$ for $1 \mathrm{~min}\left(0.27\right.$ seeds $\left.\mathrm{h}^{-1}\right)$ at $36 \mathrm{~h}$ after seeding (Figure 2D). In GP, at 120 h, 48 and 55\% of the
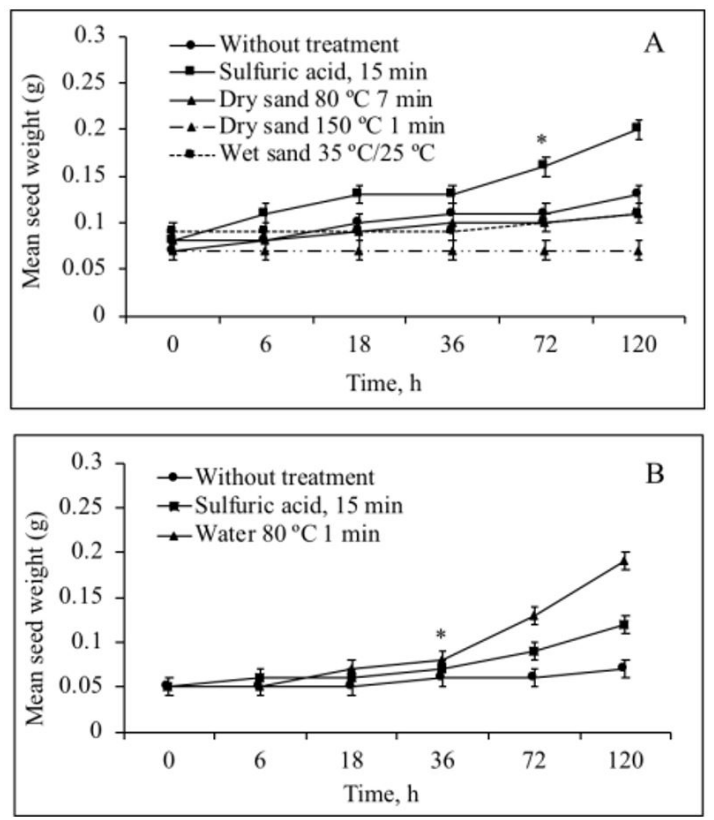

Figure 3. Accumulated seed weight (water absorption) of L. exaltatus (A) and C. longirostrata (B) after application of scarification treatments over time. *Start of germination. Error bars represent \pm s.e. $(n=3)$.
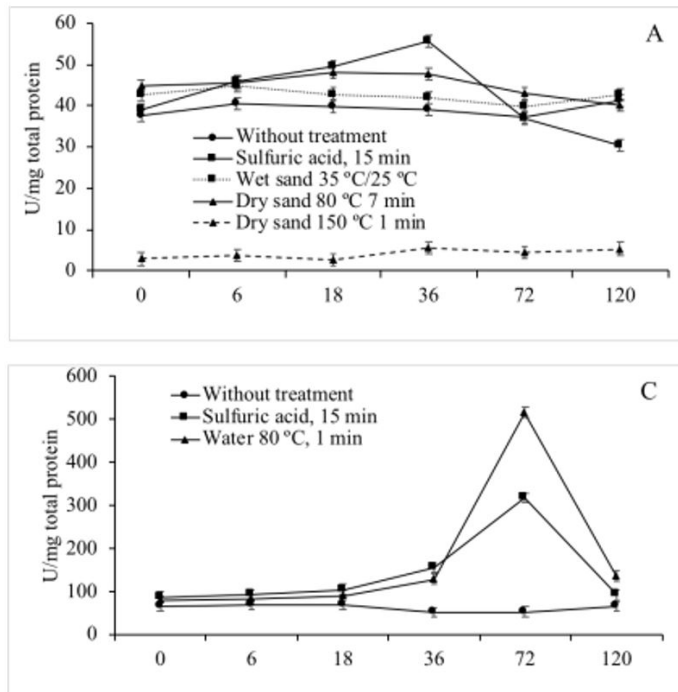

seeds germinated after sulfuric acid $98 \%$ and water at $80^{\circ} \mathrm{C}$ treatment, respectively.

Water absorption was faster in L. exaltatus seeds after application of sulfuric acid $98 \%$ for 15 min (Figure 3A), than in the other scarification pre-treatments during early germination. No seed weight gain was observed after application of dry heat at $150^{\circ} \mathrm{C}$ treatment. In C. longirostrata, from $72 \mathrm{~h}$ after imbibition, water absorption increased after application of water at $80{ }^{\circ} \mathrm{C}$ for $1 \mathrm{~min}$ followed by sulfuric acid $98 \%$ for 15 min pre-treatment (Figure 3B). At this time, the increase in the growth of the embryo and radicle emergence affected seed weight due to as more than $50 \%$ of seeds began germination.

During early germination, in L exaltatus, heat shock pre-treatment (dry sand $150^{\circ} \mathrm{C}$ ) that completely inhibited GP, also inhibited enzyme activity (Figure 4A and 4B). The $\alpha$-D-galactosidase activity increased after acid pre-treatment to $36 \mathrm{~h}$, and then declined (Figure 4A). The maximum peak activity of this enzyme was found at $36 \mathrm{~h}$ (55.6 U/mg total protein). Enzymatic activity of $\beta$-glucosidase was no significantly different $(\mathrm{p} \geq 0.05$ ) between the pre-treatments (Figure 4B). In C. longirostrata, the highest $\alpha$-D-galactosidase activity was observed at $72 \mathrm{~h}$ with treatment of immersion in water at $80{ }^{\circ} \mathrm{C} 1 \mathrm{~min}$ (Figure 4C), followed by those of sulfuric acid $98 \%$ pre-treatment. At time $120 \mathrm{~h}$, both pre-treatments showed close to or more than $50 \%$ germination (Figure 2C), just as the enzyme activity decreased significantly. Indicating that once most of seeds germinated, the activity of $\alpha$-D-galactosidase decreased. The highest concentration of $\beta$-glucosidase activity was found in the seeds treated with sulfuric acid at time $0(3.77 \mathrm{U} / \mathrm{mg}$ total protein $)$ (Figure 4D).
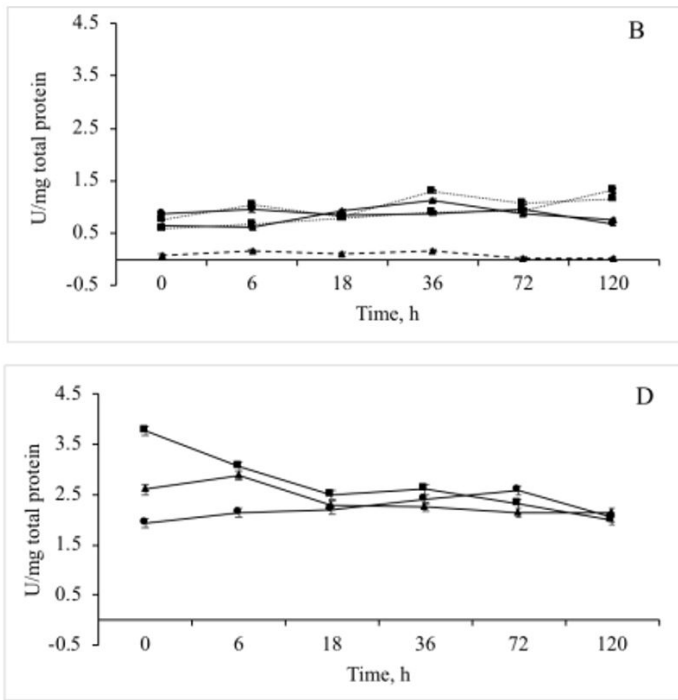

Figure 4. Specific activity of $\alpha$-D-galactosidase and $\beta$-glucosidase in L. exaltatus (A, B) and C. longirostrata (C, D) seeds during early germination time, after subjected to scarification treatments. Different letters by enzyme are statistically different (Tukey, $\mathrm{p} \leq 0.05)$. Error bars represent \pm s.e. $(\mathrm{n}=3)$. 


\section{Discussion}

Seeds of C. longirostrata and L. exaltatus need scarification to increase water absorption (Ayala-Herrada et al., 2010; Pablo-Pérez et al., 2013) and initiate metabolic changes to carry out the germination process. Scarification with sulfuric acid $98 \%$ to soften the seed coat had a significant effect on the germination percentage and rate in the two species. In L. exaltatus GP was $31 \%$ at $120 \mathrm{~h}$ after seeding and $34 \%$ at 30 DAS. In studies with L. leptophyllus the application of this acid promoted $15 \%$ of germination at 120 h (Alderete-Chávez et al., 2010a). A higher germination percentage has been observed in other Lupinus species. In L. campestris seeds, sulfuric acid also broke dormancy, but with 90 min of exposure, peaking at $50 \%$ at 30 DAS (Gutierrez-Nava et al., 2010). Dry heat treatment did not promote germination in L. exaltatus from study area after 30 DAS. Nevertheless, L. exaltatus growing in areas prone to accidental fires in the state of Jalisco, Mexico, shows 93\% of germination seven weeks after seeding, when exposed to heat shock at $150^{\circ} \mathrm{C} 1 \mathrm{~min}$ (Zuloaga-Aguilar et al., 2010). The results obtained suggest that a longer germination time could be necessary to evaluate these pre-treatments of dry heat in this species from Puebla, Mexico, although in the genus Lupinus has been observed a high variation in germination, in response to pre-germination treatments (Elliott et al., 2011).

Different studies in Crotalaria spp. have shown a positive effect of using acid sulfuric to release dormancy and promote germination. In C. longirostrata from Oaxaca, Mexico, application of sulfuric acid $98 \%$ for $60 \mathrm{~min}$ resulted in $99 \%$ of germination at seven days (Ayala-Herrada et al., 2010), but in C. retusa with 20 min of acid exposure was only $20 \%$ at 5 DAS (Alderete-Chávez et al., 2010b). In Crotalaria seeds from Tabasco, Mexico it was observed $48 \%$ of germination at $5 \mathrm{DAS}$ with sulfuric acid for $15 \mathrm{~min}$. But using water $80^{\circ} \mathrm{C} 1 \mathrm{~min}$, the germination percentage was increased to $55 \% 5$ DAS and $>60 \% 30$ DAS. Muñoz et al. (2009) observed a similar response in seeds of Crotalaria cv. right to acid treatment, despite seeds had more than 12 years of storage.

High specific activity of $\alpha$-D-galactosidase was observed in seeds of both species as of five DAS. Kadlec et al. (2008) observed that in soybeans, peas and lupine seeds levels of $\alpha$-galactosides decrease during the first two days of imbibition, and hydrolysis takes 4 to 5 days. In Tachigali multijuga (Fialho et al., 2008) an increase in $\alpha$-D-galactosidase activity was detected the first $108 \mathrm{~h}$ of imbibition. This enzyme catalyzes hydrolysis of galactans in the cell walls of L. angustifolius cotyledons during early stages of germination (Buckeridge et al., 2005). In this study, changes in the activity of enzymes tested occurred during the first hours of imbibition. Acid scarification treatment modified enzymatic activity of $\alpha$-D-galactosidase during the first $120 \mathrm{~h}$, and this increase was when the germination percentage was high. In C. longirostrata, the enzyme showed higher activity at $72 \mathrm{~h}$ after application of treatments. In L. exaltatus, at $36 \mathrm{~h}$ after sulfuric acid treatment. As previously indicated, this enzyme has the ability to hydrolyze both stachyose and raffinose sugars and galactomannans in the cell walls of cotyledons to support radicle emergence (Bewley et al., 2013; Buckeridge et al., 2005). As increase $\alpha$-galactosidase activity, raffinose and stachyose content decrease (Fialho et al., 2008). The $\beta$-glucosidase activity did not show relation with germination percentage although several studies mentioned their involvement in germination process (Singh et al., 2016; Minic, 2008).

In conclusion, sulfuric acid treatment increases GP and GR in both species. In seeds of $C$. longirostrata, scarification treatment using hot water may be an alternative scarification treatment as it also showed a high GP. During early germination of the seeds of both species, between 36 and $76 \mathrm{~h}$ after seeding the increase in GP is accompanied by a rise in $\alpha$-D-galactosidase activity.

\section{Acknowledgements}

Authors are grateful to Consejo Nacional de Ciencia y Tecnología (CONACYT, project CB-2012-01 181428) and CP (project 449), for funding the study. The first author is grateful to CONACYT for the scholarship granted to pursue graduate studies.

\section{References}

ACOSTA-PERCÁSTEGUI, J. and RODRÍGUEZ-TREJO, D.A., 2005 [viewed 26 September 2017]. Factors affecting germination and pregerminative treatments of Lupinus montanus seeds. Interciencia [online], vol. 30, pp. 576-579. Available from: http://www.redalyc.org/articulo.oa?id=33910811

ALDERETE-CHÁVEZ, A., RODRÍGUEZ-TREJO, D.A., ESPINOSA-HERNÁNDEZ, V., OJEDA-TREJO, E. and DE LA CRUZ-LANDERO, N., 2010a. Effects of different scarification treatments on the germination of Lupinus leptophyllus seeds. International Journal of Botany, vol. 6, no. 1, pp. 64-68. http:// dx.doi.org/10.3923/ijb.2010.64.68.

ALDERETE-CHÁVEZ, A., AGUILAR-MARIN, L., DE LA CRUZ-LANDERO, N., GUERRA-SANTOS, J.J., BRITO, R., GUEVARA, E. and GELABERT, R., 2010b. Effects of scarification chemical treatments on the germination of Crotalaria retusa L. seeds. The Journal of Biological Sciences, vol. 10, no. 6, pp. 541-544. http://dx.doi.org/10.3923/jbs.2010.541.544.

AYALA-HERRADA, L., VILLAFAÑE-CRUZ, M., PINACHOLOPEZ, B., ARROYO-LEDEZMA, J. and MAGAÑASEVILLA, H., 2010. Escarificación de semillas de Indigofera hirsuta (Linneaus), Canavalia maritima (Thouars) y Crotalaria longirostrata (Hook). Revista de la Facultad de Agronomía, vol. 27, pp. 433-446.

BEWLEY, J.D., BRADFORD, K.J., HILHORST, H.W.M. and NONOGAKI, H., 2013. Seeds: physiology and dormancy. 3rd ed. New York: Springer. http://dx.doi.org/10.1007/978-1-4614-4693-4.

BUCKERIDGE, M.S., 2010. Seed cell wall storage polysaccharides: models to understand cell wall biosynthesis and degradation. Plant Physiology, vol. 154, no. 3, pp. 1017-1023. http://dx.doi. org/10.1104/pp.110.158642. PMid:20855518.

BUCKERIDGE, M.S., HUTCHEON, I.S. and REID, J.S.G., 2005 . The role of exo- $(1,4)-\beta$-galactanase in the mobilization of polysaccharides from the cotyledon cell walls of Lupinus angustifolius following germination. Annals of Botany, vol. 
96, no. 3, pp. 435-444. http://dx.doi.org/10.1093/aob/mci192. PMid:15994843.

ELLIOTT, C.A., FISCHER, D.G. and LE ROY, C.J., 2011. Germination of three native Lupinus species in response to temperature. Northwest Science, vol. 85, no. 2, pp. 403-410. http://dx.doi.org/10.3955/046.085.0223.

FIALHO, L.S., GUIMARÃES, V.M., CALLEGARI, C.M., REIS, A.P., BARBOSA, D.S., BORGES, E.E.L., MOREIRA, M.A. and REZENDE, S.T., 2008. Characterization and biotechnological application of an acid a-galactosidase from Tachigali multijuga Benth. seeds. Phytochemistry, vol. 69, no. 14, pp. 2579-2585. http:// dx.doi.org/10.1016/j.phytochem.2008.08.017. PMid:18834998.

FRAILE, M.E., GARCÍA-SUÁREZ, M.D., MARTÍNEZBERNAL, A. and SLOMIANSKI, R., 2007. Nutritivas y apetecibles: conozca de leguminosas comestibles. Parte I: hojas, vainas y semillas. Contactos, vol. 66, pp. 27-35.

GALlardo, K., JOB, C., GROOT, S.P.C., PUYPE, M., DEMOL, H., VANDEKERCKHOVE, J. and JOB, D., 2002. Proteomics of Arabidopsis seed germination: a comparative study of wild-type and gibberellin-deficient seeds. Plant Physiology, vol. 129, no. 2, pp. 823-837. http://dx.doi.org/10.1104/pp.002816. PMid:12068122.

GERARDI, C., BLANDO, F., SANTINO, A. and ZACHEO, G., 2001. Purification and characterisation of a $\beta$-glucosidase abundantly expressed in ripe sweet cherry (Prunus avium L.) fruit. Plant Science, vol. 160, no. 5, pp. 795-805. http://dx.doi. org/10.1016/S0168-9452(00)00423-4. PMid:11297776.

GUIMARÃES, V.M., REZENDE, S.T., MOREIRA, M.A., BARROS, E.G. and FELIX, C.R., 2001. Characterization of $\alpha$-galactosidases from germinating soybean seed and their use for hydrolysis of oligosaccharides. Phytochemistry, vol. 58, no. 1, pp. 67-73. http://dx.doi.org/10.1016/S0031-9422(01)00165-0. PMid:11524115.

GUTIÉRREZ NAVA, P., DE LEÓN GONZÁLEZ, F., ETCHEVERS BARRA, J. and CASAS FERNÁNDEZ, A., 2010. Effect of scarification, self-inhibition, and sowing depth on seed germination of Lupinus campestris. Chilean Journal of Agricultural Research, vol. 70, no. 3, pp. 365-371. http://dx.doi. org/10.4067/S0718-58392010000300003.

JELLER, H., PEREZ, S.C.J.G.A. and RAIZER, J., 2003. Water uptake, priming, drying and storage effects in Cassia excelsa Schrad seeds. Brazilian Journal of Biology $=$ Revista Brasileira de Biologia, vol. 63, no. 1, pp. 61-68. http://dx.doi.org/10.1590/ S1519-69842003000100008. PMid:12914415.

KADLEC, P., DOSTÁlOVÁ, J., BERNÁŠKOVÁ, J. and SKULINOVÁ, M., 2008. Degradation of $\alpha$-galactosides during the germination of grain legume seeds. Czech Journal of Food Sciences, vol. 26, no. 2, pp. 99-108. http://dx.doi.org/10.17221/3/2008-CJFS.

KAMITHI, K.D., WACHIRA, F. and KIBE, A.M., 2016 [viewed 26 September 2017]. Effects of different priming methods and priming durations on enzyme activities in germinating chickpea (Cicer arietinum L.). American Journal of Natural and Applied Sciences [online], vol. 1, pp. A1-A9. Available from: http://www. ASRAresearch.org/ajnas-vol-1-no-1-2016

LAGUNES-ESPINOZA, L.C., LÓPEZ-UPTON, J., GARCÍALÓPEZ, E., JASSO-MATA, J., DELGADO-ALVARADO, A. and GARCÍA DE LOS SANTOS, G., 2012. Diversidad morfológica y concentración de proteína de Lupinus spp. en la región centro-oriental del estado de Puebla, México. Acta Botánica Mexicana, vol. 99, no. 99, pp. 73-90. http://dx.doi.org/10.21829/ abm99.2012.20.
LIEW, L.C., SINGH, M.B. and BHALLA, P.L., 2014. Unique and conserved features of floral evocation in legumes. Journal of Integrative Plant Biology, vol. 56, no. 8, pp. 714-728. http:// dx.doi.org/10.1111/jipb.12187. PMid:24930396.

MAGUIRE, J.D., 1962. Speed of germination: aid in selection and evaluation for seedling emergence and vigour. Crop Science, vol. 2, no. 2, pp. 176-177. http://dx.doi.org/10.2135/cropsci1962 .0011183 X000200020033x.

MARKWELL, M.A.K., HAAS, M., BIEBER, L.L. and TOLBERT, N.E., 1978. A modification of the Lowry procedure to simplify protein determination in membrane and lipoprotein samples. Analytical Biochemistry, vol. 87, no. 1, pp. 206-210. http://dx.doi.org/10.1016/0003-2697(78)90586-9. PMid:98070.

MINIC, Z., 2008. Physiological roles of plant glycoside hydrolases. Planta, vol. 227, no. 4, pp. 723-740. http://dx.doi.org/10.1007/ s00425-007-0668-y. PMid:18046575.

MUÑOZ, C.B., SÁNCHEZ, J.A., MONTEJO, L.A., GONZÁLEZ, Y. and REINO, J., 2009. Valoración germinativa de 20 accesiones de leguminosas almacenadas en condiciones desfavorables. Pastos y Forrajes, vol. 32, pp. 1-15.

PABLO-PÉREZ, M., LAGUNES-ESPINOZA, L.C., LÓPEZUPTON, J., RAMOS-JUÁREZ, J. and ARANDA-IBÁÑEZ, E.M., 2013. Morfometría, germinación y composición mineral de semillas de Lupinus silvestres. Bioagro-, vol. 25, pp. 101-108.

ROSS, S.G., REDGWELL, R.J. and MACRAE, E.A., 1993. Kiwifruit $\beta$-galactosidase: Isolation and activity against specific fruit cell-wall polysaccharides. Planta, vol. 189, no. 4, pp. 499506. http://dx.doi.org/10.1007/BF00198212.

SINGH, G., VERMA, A.K. and KUMAR, V., 2016. Catalytic properties, functional attributes and industrial applications of $\beta$-glucosidases. 3 Biotech, vol. 6, no. 1, pp. 1-14. http://dx.doi. org/10.1007/s13205-015-0328-z. PMid:28330074.

SMÝKAL, P., VERNOUD, V., BLAIR, M., SOUKUP, A. and THOMPSON, R., 2014. The role of the testa during development and in establishment of dormancy of the legume seed. Frontiers in Plant Science, vol. 5, pp. 351. http://dx.doi.org/10.3389/ fpls.2014.00351. PMid:25101104.

SOTO-CORREA, J.C., SÁENZ-ROMERO, C., HORACIO, H. and LINDIG-CISNEROS, R., 2015. Estrés por sequía en Lupinus elegans procedentes de diferentes altitudes. Madera y Bosques, vol. 21, no. 1, pp. 35-43. http://dx.doi.org/10.21829/ myb.2015.211431.

SOUSA, S.M. and DELGADO, S.A., 1998. Leguminosas mexicanas: fitogeografía, endemismo y orígenes. In: T.P. RAMAMOORTHY, R. BYE, A. LOT and J. FA, eds. Diversidad biológica de México: orígenes y distribución. México: Instituto de Biología, UNAM, pp. 449-500.

SUDA, N.K.C., BUCKERIDGE, M.S. and GIORGINI, J.F., 2003. Cell wall hydrolases in the seeds of Euphorbia heterophylla L. during germination and early seedling development. Brazilian Journal of Plant Physiology, vol. 15, no. 3, pp. 135-143. http:// dx.doi.org/10.1590/S1677-04202003000300002.

TIRYAKI, I. and TOPU, M., 2014. A novel method to overcome coat-imposed seed dormancy in Lupinus albus L. and Trifolium pratense L. Le Journal de Botanique, vol. 1, pp. 1-6. http://dx.doi. org/10.1155/2014/647469.

ZULOAGA-AGUILAR, S., BRIONES, O. and OROZCOSEGOVIA, A., 2010. Effect of heat shock on germination of 23 plant species in pine-oak and montane cloud forests in western Mexico. International Journal of Wildland Fire, vol. 19, no. 6, pp. 759-773. http://dx.doi.org/10.1071/WF08092. 